juice or its derivatives acts in a more indirect way ; it may be mentioned that transmission of kala azar by the blood-sucking sand fly Phlebotomus argentipes Annandale and Brunetti is influenced by fruit feeding.

The implications of these findings are now being studied. In the meantime it is clear that much more consistent results are obtained when this uncontrolled variable is removed. Other work has failed to produce evidence for an ovarian development hormone in $A$. aegypti ${ }^{2}$, but it is not known how far this failure may have been due to differences in technique.

$$
\text { J. D. GilletT }
$$

East African Virus Research Institute, Entebbe, Uganda.

$$
\text { May } 4 .
$$

${ }^{2}$ Detinova, T. S., Zool. Zh., 24, 291 (1945).

${ }^{2}$ Clements, A. N., J. Exp. Biol., 33, 211 (1956).

${ }^{3}$ Gillett, J. D., Ann. Trop. Med. Parasit., 50, 375 (1956).

"Christophers, S. R., "Paludism", 2, 73 (1911).

${ }^{5}$ Gillett, J. D., Ann. Trop. Med. Parasit., 50, 362 (1956)

- MacGregor, M. E., and Lee, C. U., Trans. Roy. Soc. Trop. Med. Hyg., 23, 203 (1929).

' MacGregor, M. E., Trans. Roy. Soc. Trop. Med. Hyg., 23, 329 (1929).

${ }^{8}$ Shortt, H. E., Trans. Roy. Soc. Trop. Med. Hyg., 39, 13 (1945).

\section{Hæmagglutinins in Calpurnia aurea}

AGGLUTININS acting strongly on suspensions of human group A and B erythrocytes in isotonic saline, and weakly or not at all on those of group $\mathrm{O}$, are present in the seeds of Sophora japonica ${ }^{1}$, Coronilla varia $^{1}$, Crotalaria striata ${ }^{2}$, and in recently harvested samples of Bandeiraea simplicifolia ${ }^{3}$. The agglutinins of Sophora japonica, Coronilla varia and Bandeiraea simplicifolia act more powerfully, and to much higher titres, on B cells than on A cells ; the reverse being true of those of Crotalaria striata.

During an investigation of agglutinins in plants available in Britain, another source of anti- $(A+B)$ agglutinins was found in the seeds of Calpurnia aurea (butterfly bush or South African laburnum). The agglutination titres of crude isotonic saline extracts of these seeds ( 1 vol. seed material : 10 vol. saline) for saline suspensions of human erythrocytes are : $\mathrm{A}_{1}, 256 ; \mathrm{A}_{2}, 32 ; \mathrm{B}, 128$; $\mathrm{O}$, nil. Their general serological properties are similar to those of the agglutinins previously described. A single agglutinin is present, which can be absorbed by either A or B erythrocytes and eluted therefrom, the eluates having the same properties as the original extract. Treatment with $\mathrm{A}$ or $\mathrm{B}$ blood group specific substance, or with the simple sugars $\mathrm{N}$-acetylgalactosamine and D-galactose, which are structurally related to the $A$ and $B$ substances respectively ${ }^{4}$, inhibits activity with both $\mathrm{A}$ and $\mathrm{B}$ cells. L-fucose, N-acetylglucosamine and L-galactose do not inhibit when tested in similar concentrations. Unlike those previously described, the agglutinins are almost equally active with $A_{1}$ and $B$ cells; $O$ cells are not agglutinated when kept at $0^{\circ} \mathrm{C}$. overnight or when suspended in albumin. Papainized O cells, however, are weakly agglutinated.

It appears that these agglutinins are better adapted to the chemical configuration common to the human blood group antigens $\mathbf{A}$ and $\mathbf{B}$ than any previously obtained from seeds; that is, they provide the hitherto closest approximation to the "crossreacting' or 'anti-C' agglutinins of certain human O sera ${ }^{5}$.
Full serological details, and a discussion of the possible value of these agglutinins in routine blood grouping and blood group research, will be presented elsewhere.

\section{Lister Institute, \\ London, S.W.1.}

G. W. G. BIRD

May 1.

1 Krüpe, M., Biol. Zbl., "72, 424 (1953).

${ }^{2}$ Bird, G. W. G., Vox Sang., New Series, 1, 167 (1956).

${ }^{8}$ Mäkelä, O., and Mäkelä, P., Ann. Med. Exp. Fenn., 34, 402 (1956).

- Morgan, W. T. J., and Watkins, W. M., Brit. J. Exp. Path., 34, 94 (1953). 'Race, R. R., and Sanger, R., "Blood Groups in Man" (Oxford,
1954).

\section{An Investigation of an Action of Penicillin}

Prevrous work ${ }^{1}$ has suggested that amiphenazole (2:4-diamino-5-phenylthiazole hydrochloride, 'Daptazole', 'DHA 245') may enter, after a period of delay (1-3 weeks), into the thiamine metabolism of weanling rats maintained on a thiamine-free diet.

The expectation that penicillin, which is a $2: 4: 5$ trisubstituted thiazolidine derivative, might likewise influence biological processes requiring thiamine, was assessed by its ability to support the growth, in the absence of thiamine or its thiazole moiety (4-methyl-5-hydroxyethyl-thiazole), of the mould Phycomyces blakesleeanus ${ }^{2}$ and the weanling rat $(40-50 \mathrm{gm} .)^{1,3}$.

Table 1 indicates that the presence of penicillin, thiamine or its thiazole moiety was essential for the growth of the mould during a 14-day period at $20^{\circ} \mathrm{C}$. on an artificial medium ${ }^{2}$ containing the pyrimidine moiety of thiamine (2-methyl-4-amino-5-ethoxymethyl pyrimidine).

Penicillin can therefore replace the thiazole moiety of thiamine as a growth factor for the mould.

\begin{tabular}{|c|c|}
\hline Basal medium ${ }^{2}$ plus & $\begin{array}{c}\text { Degree of growth }\left(20^{\circ} \mathrm{C} .\right) \\
\text { after } 14 \text { days }\end{array}$ \\
\hline $\begin{array}{l}\text { No added factor } \\
\text { Pyr }\left(4 \times 10^{-7} M\right) \\
\text { Pyr } \\
\left(4 \times 10^{-9} M\right)+\left(4 \times 10^{-9} M\right) \\
\text { Thiamine } \\
\left(4 \times 10^{-9} M\right) \\
\left(4 \times 10^{-7} M\right)+\left(4 \times 10^{-4} M\right)\end{array}$ & $\begin{array}{l}- \\
++ \\
++ \\
++\end{array}$ \\
\hline
\end{tabular}
Table 1. EfFect of Penicillin on the Growth of Phycomyces

- signifies no growth

+ - signifies growth with aerial hyphæ

Pyr = 2-Methyl-4-amino-5-ethoxymethyl pyrimidine
Th = 4-Methyl-5-hydroxyethyl-thiazole

Pen $=$ Crystalline sodium benzylpenicillin

The concentrations of penicillin and the thiazole moiety of thiamine or thiamine required to give a comparable weight of mycelium were in the ratio of 100,000 to 1 .

Further, penicillin $\left(4 \times 10^{-4} M\right)$ supplemented a suboptimal concentration of the thiazole moiety of thiamine $\left(4 \times 10^{-8} M\right)$ to give an increased mycelial weight.

Table 2 illustrates the beneficial effect of intraperitoneal administration of penicillin, either alone or with the pyrimidine moiety of thiamine, on weanling rats maintained on a thiamine-free diet ${ }^{4}$. It both delayed the onset of thiamine deficiency and 